\title{
The ligule ultrastructure of the tidal swamp rice (Oryza sativa) landraces of South Kalimantan, Indonesia, and their genetic diversity and relationship
}

\author{
DINDIN HIDAYATUL MURSYIDIN ${ }^{1}$, PURNOMO ${ }^{2}$, BUDI SETIADI DARYONO ${ }^{3, \bullet}$ \\ ${ }^{1}$ Laboratory of Genetics and Molecular Biology, Faculty of Mathematics and Natural Sciences, Universitas Lambung Mangkurat. Jl. A. Yani Km. 36, \\ Banjarbaru 70714, South Kalimantan, Indonesia \\ ${ }^{2}$ Laboratory of Plant Systematics, Faculty of Biology, Universitas Gadjah Mada. Jl. Teknika Selatan, Sleman 55281, Yogyakarta, Indonesia \\ ${ }^{3}$ Laboratory of Genetics and Breeding, Faculty of Biology, Universitas Gadjah Mada. Jl. Teknika Selatan, Sleman 55281, Yogyakarta, Indonesia. \\ Tel.: +62-274-580839, vemail: bs_daryono@ mail.ugm.ac.id
}

Manuscript received: 22 August 2021. Revision accepted: 9 November 2021.

\begin{abstract}
Mursyidin DH, Purnomo, Daryono BS. 2021. The ligule ultrastructure of the tidal swamp rice (Oryza sativa) landraces of South Kalimantan, Indonesia, and their genetic diversity and relationship. Biodiversitas 22: 5280-5285. In-depth characterization of rice landrace is needed in supporting the future conservation and crop breeding programs. Tidal swamp rice (Oryza sativa L.), belonging to this landrace, provided useful agronomic traits for both programs. In this study, the nine the tidal swamp rice ligule samples, mainly from South Kalimantan, Indonesia, were observed ultrastructurally using the SEM method. The diversity and relationships of this landrace based on the ligule ultrastructure were also determined using PCA and UPGMA methods. Generally the tidal swamp rice showed a unique ultrastructure of their ligule, composed of the large trichomes (prickle hair), small trichomes (micro hair), stomata-like structure, and silica cells, as well as the papillae that line along the veins. In this case, we found four patterns of the prickle hair on the ligule's abaxial surface, which has never been reported previously, namely scattered randomly, lined up on the vein, grid-step-like pattern, and unpatterned. The results of PCA and UPGMA showed that this landrace grouped into the same main three clusters, where Sardani (an outgroup) was included in the second cluster and joined with other cultivars from South Kalimantan. This information may be useful for the development of taxonomy and plant structures, and plant genetics and conservation.
\end{abstract}

Keywords: Conservation, multivariate analysis, plant breeding, plant structure, SEM

Abbreviations: PCA: Principal Component Analysis; SEM: Scanning Electron Microscopy; UPGMA: Unweighted Pairs Group Method with Arithmetic Average

\section{INTRODUCTION}

Since rice is consumed as a staple food by more than half of the global human population with such growth rapidly (Amanullah et al. 2017; Fukagawa and Ziska 2019), most of the rice breeding programs are focused on producing high-yielding cultivars (Khan et al. 2015; Collard et al. 2017; Rabara et al. 2018). Hence, observing the rice genetic resources that have some agronomic advantages becomes very urgent to employ (Wambugu et al. 2013; Patra et al. 2016; Lee et al. 2020). Tidal swamp rice, which belongs to traditional or local rice landrace, provided useful agronomic traits for the programs (Azeez et al. 2018; Mursyidin et al. 2019). However, this germplasm shows the important agronomic traits, related to stress tolerance, high yielding stability, and adaptability to local conditions (Azeez et al. 2018). Moreover, tidal swamp rice contains several essential genes as well, it is related to acidity tolerance, salinity, and metals contamination (Samal et al. 2016; Rao et al. 2018).

In South Kalimantan, Indonesia, one of the biggest rice producers in this country, hundreds of tidal swamp rice landraces are found (Mursyidin et al. 2017). Since 1920, the local people of this region, particularly the Banjarese tribe, have known Bayar as an important tidal swamp rice cultivar. Besides this cultivar, the Banjarese also knows three others, namely Lemo, Siam, and Pandak (Mursyidin et al. 2017). However, most rice landraces are not wellcharacterized and, at the same time, being replaced (disappeared) due to adopting the 'green revolution' cultivars with high-yielding productivity (Nourollah 2016).

In many decades, the characterization of the rice landraces has been employed based on morphological markers, particularly on macro-structural levels (Sinha et al. 2015; Islam et al. 2018). But nowadays, ultrastructure analysis using the SEM method is an alternative way to characterize germplasm, including the landraces of rice (Mursyidin et al. 2018; Roy and Shil 2020). This method is reliable and shows more accurate results than the macrostructural method in characterizing the rice germplasm (Kasem et al. 2011). Furthermore, the ultrastructure method could be useful as a complement to the other one (Roy and Shil 2020).

Since the ligule is used as a marker for distinguishing rice plants from other grasses (Poaceae), even among the Oryza genus (Nayar 2014), in addition to other functions, 
this specific organ is very much studied (Chaffey 1983). Physiologically, this organ can protect the plant from excluding water, dust, or harmful spores from the outside environment (Chaffey 2000; Simpson 2019). Morphologically, the rice ( $O$. sativa) ligule is triangular, attached to the sheath, and located in the middle and close to the auricle. Based on our earlier studies (Mursyidin et al. 2019), the tidal swamp rice has a similar ligule structure, namely the triangular shapes with 2-cleft in the pointed tip.

Here, we are focused on investigating the ligule ultrastructure of the tidal swamp rice landraces from South Kalimantan, Indonesia, using the SEM method and determining their diversity and relationships using UPGMA methods. Such a study, however, is very limited in the cultivated rice $(O$. sativa), except for some wild rice, such as O. latifolia (Sánchez et al. 2003), O. glumaepatula (Sánchez and Espinoza 2005), and O. grandiglumis (Sánchez et al. 2006). Thus, these results could support a positive contribution to taxonomy, plant structure, and genetics. Besides, these results are useful for future rice breeding and conservation programs, both locally and globally.

\section{MATERIALS AND METHODS}

\section{Plant materials}

We have used a total of nine indigenous cultivars of tidal swamp rice, including eight from the South Kalimantan, Indonesia, and one from South Sumatra, Indonesia (Table 1). The last sample was obtained from the Indonesian Swampland Agriculture Research Institute (ISARI), South Kalimantan, Indonesia, and used as an outgroup. The sampling sites where the tidal swamp rice was collected can be seen in Figure 1.

\section{Sample preparation}

The sampling of ligules was prepared according to Mursyidin et al. (2018). This activity was started by fixation, where the ligule samples were fixed with $2.5 \%$ glutaraldehyde and $2 \%$ paraformaldehyde in $0.1 \mathrm{M}$ sodium phosphate buffer ( $\mathrm{pH}$ 7.4). Then the samples were washed with the sodium phosphate buffer and were fixed with $1 \%$ osmium tetraoxide in the $0.1 \mathrm{M}$ sodium phosphate buffer. After that, the preparation is followed by samples washed with distilled water and dehydrated in an ethanol gradient. Once completed, samples were rewashed with terbutaline alcohol four times and dried using freeze-drying methods.
At the final preparation stage, the samples were mounted on aluminum bases, covered with $20 \mathrm{~nm}$ of gold (using ionic coater), and ready to observe by scanning electron microscope.

\section{SEM analysis}

The rice ligule ultrastructure was analyzed by scanning electron microscope (JEOL JSM-5000, Japan) in an acceleration voltage of $20 \mathrm{kV}$. This analysis was conducted at the SEM Laboratory, Research Center of Biology, Indonesian Science Institute (LIPI), Bogor, Indonesia. SEM photomicrograph was taken uniformly for all samples, at a magnification of $\times 500$.

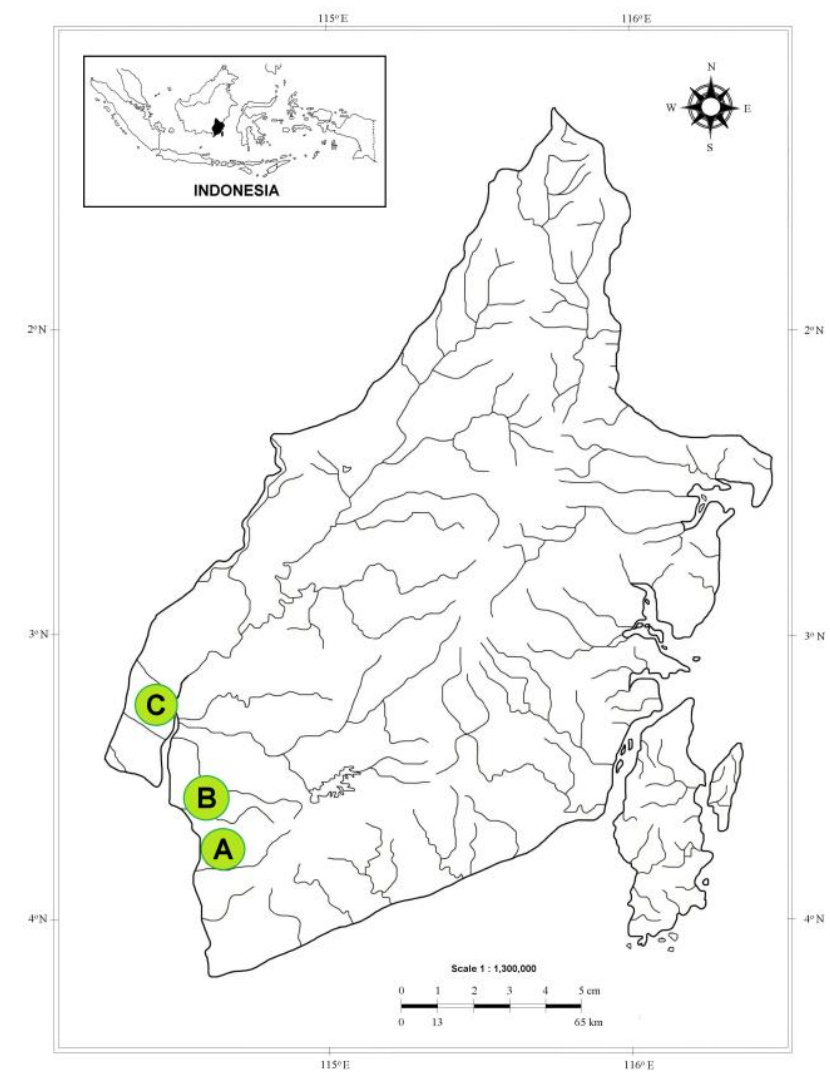

Figure 1. A map of South Kalimantan, Indonesia showing the sampling sites where the tidal swamp rice was collected, including the regency of Tanah Laut (A), Banjar (B), and Barito Kuala (C)

Table 1. A list of the tidal swamp rice cultivars employed in this study

\begin{tabular}{|c|c|c|c|c|}
\hline Cultivars & Code & Genetic status & Subspecies & Origin \\
\hline Siam Gadis & A & Landrace & Javanica & Tanah Laut, South Kalimantan \\
\hline Karang Dukuh & $\mathrm{B}$ & Landrace & Indica & Barito Kuala, South Kalimantan \\
\hline Ciherang & $\mathrm{C}$ & Improved & Javanica & Banjar, South Kalimantan \\
\hline Lakatan Pacar & $\mathrm{D}$ & Landrace & Javanica & Banjar, South Kalimantan \\
\hline Banih Kuning & $\mathrm{E}$ & Landrace & Javanica & Banjar, South Kalimantan \\
\hline Ganal Perak & $\mathrm{F}$ & Landrace & Javanica & Banjar, South Kalimantan \\
\hline Sardani* & $\mathrm{G}$ & Landrace & Indica & South Sumatera \\
\hline Pandak Putih & $\mathrm{H}$ & Landrace & Javanica & Banjar, South Kalimantan \\
\hline Lakatan Wangi & $\mathrm{I}$ & Landrace & Javanica & Banjar, South Kalimantan \\
\hline
\end{tabular}

Note: *An outgroup 


\section{Data analysis}

The ligule ultrastructure of each cultivar was analyzed descriptively. The data were then tabulated, transformed, and standardized into numerical values with the assistance of MPSV ver. 3.1 software (Kovach 2007). The diversity indices were calculated by Shannon's diversity index $(\mathrm{H})$, following a formula:

$$
H^{r}=-\sum p i\left(\log _{2} p i\right) / \log _{2} N
$$

Where, $p \mathrm{i}$ is the frequency proportion of the descriptor state, and $n$ is the number of observed states. The level of diversity indices was referred to Rabara et al. (2014), with criteria for maximum level $(\mathrm{H}=1.00)$, high $(\mathrm{H}=0.76$ $0.99)$, moderate $(\mathrm{H}=0.46-0.75)$ and low diversity $(0.01$ 0.45). Multivariate statistical analyses were employed in determining the principal component (PCA) and cluster (UPGMA) analyses. PCA was carried out to recognize the distinctive ultrastructural traits that contributed to the most variance in the measured variables (Rabara et al. 2014). UPGMA was applied to generate the distance matrix and phenetic relationships (dendrogram). Both analyses were done using the assistance of MVSP ver. 3.1 software (Kovach 2007).

\section{RESULTS AND DISCUSSION}

\section{The ligule ultrastructure}

The ultrastructure in tidal swamp rice ligule of South Kalimantan, Indonesia, showed a unique feature (Figure 2). In general, the structure of this organ composed of large trichomes (prickle hair), small trichomes (micro hair), stomata-like structure, silica cells, and the papillae that line along the veins. However, based on further observation, each component of the ligule showed differences, both in their characteristics or pattern (Table 2), and density (Table 3).

Based on Table 2, there were four types of prickle hair patterns on the tidal swamp rice ligule, namely scattered randomly, lined up on the vein, grid-step-like pattern, and unpatterned. The first pattern, scattered randomly, is shown by Siam Gadis, Karang Dukuh, and Ciherang. The cultivars of Lakatan Pacar and Sardani, both have a grid-step-like pattern. The Banih Kuning has prickle hair, which is located line up on the vein. The three remaining cultivars (Ganal Perak, Pandak Putih, and Lakatan Wangi) showed unpatterned. Further, from the same table, there were three types of micro hair patterns, as similar as in prickle hair, except the line up on the vein pattern.

Tidal swamp rice showed a varied genetic diversity based on the ligule ultrastructure (Table 4). In general, this landrace has a diversity index of 0.50 . According to Table 4 , the prickle hair length, number of veins per $100 \mu \mathrm{m}$, and micro hair length were the highest level of diversity, with a value of $0.86,0.84$, and 0.83 , respectively. However, all of the ligule components were uncontributed to their diversity (Table 5).
Table 2. The pattern of prickle hair and micro hair on the adaxial surface of the tidal swamp rice ligule

\begin{tabular}{lcll}
\hline \multirow{2}{*}{ Cultivars } & \multirow{2}{*}{ Code } & \multicolumn{2}{c}{ Pattern of } \\
\cline { 3 - 4 } Siam Gadis & A & Scattered randomly & Scattered randomly \\
Karang Dukuh & B & Scattered randomly & Scattered randomly \\
Ciherang & C & Scattered randomly & Scattered randomly \\
Lakatan Pacar & D & Grid-step-like pattern & Grid-step-like pattern \\
Banih Kuning & E & Lined up on the vein & Scattered randomly \\
Ganal Perak & F & Unpatterned & Unpatterned \\
Sardani* & G & Grid-step pattern & Scattered randomly \\
Pandak Putih & H & Unpatterned & Grid-step-like pattern \\
Lakatan Wangi & I & Unpatterned & Scattered randomly \\
\hline Note: ${ }^{*}$ An outgroup. & &
\end{tabular}

Table 3. The density of prickle hair, micro hair, stomata-like structure, and silica cells on the adaxial surface of the tidal swamp rice ligule

\begin{tabular}{lccccc}
\hline \multicolumn{1}{c}{ Cultivars } & Code & $\begin{array}{c}\text { Prickle } \\
\text { hair }\end{array}$ & $\begin{array}{c}\text { Micro } \\
\text { hair }\end{array}$ & $\begin{array}{c}\text { Stomata- } \\
\text { like } \\
\text { structure }\end{array}$ & $\begin{array}{c}\text { Silica } \\
\text { cells }\end{array}$ \\
\hline Siam Gadis & $\mathrm{A}$ & ++ & ++ & + & - \\
Karang Dukuh & $\mathrm{B}$ & + & ++ & - & - \\
Ciherang & $\mathrm{C}$ & + & ++ & - & + \\
Lakatan Pacar & $\mathrm{D}$ & +++ & ++ & + & - \\
Banih Kuning & $\mathrm{E}$ & ++ & ++ & - & + \\
Ganal Perak & $\mathrm{F}$ & + & + & + & - \\
Sardani* & $\mathrm{G}$ & + & + & - & - \\
Pandak Putih & $\mathrm{H}$ & + & + & - & + \\
Lakatan Wangi & $\mathrm{I}$ & - & ++ & - & - \\
\hline Note: ${ }^{*}$ An outgroup & & & & &
\end{tabular}

Note: ${ }^{*}$ An outgroup

Table 4. Diversity indices of the tidal swamp rice ligule ultrastructure

\begin{tabular}{lll}
\hline \multicolumn{1}{c}{ Characters } & No. of species & $\mathbf{H}^{\prime}$ Index \\
\hline Prickle hair density & 3 & $0.28^{\mathrm{a}}$ \\
Micro hair density & 6 & $0.10^{\mathrm{a}}$ \\
Stomata-like density & 3 & $0.21^{\mathrm{a}}$ \\
Silica cell density & 3 & $0.21^{\mathrm{a}}$ \\
Prickle hair pattern & 3 & $0.75^{\mathrm{b}}$ \\
Micro hair pattern & 2 & $0.28^{\mathrm{a}}$ \\
Prickle hair length $(\mu \mathrm{m})$ & 5 & $0.86^{\mathrm{c}}$ \\
Prickle hair Width $(\mu \mathrm{m})$ & 6 & $0.14^{\mathrm{a}}$ \\
Micro hair length $(\mu \mathrm{m})$ & 4 & $0.83^{\mathrm{c}}$ \\
Micro hair Width $(\mu \mathrm{m})$ & 6 & $0.73^{\mathrm{b}}$ \\
Distant between veins $(\mu \mathrm{m})$ & 3 & $0.61^{\mathrm{b}}$ \\
Distance between papillae $(\mu \mathrm{m})$ & 1 & $0.66^{\mathrm{b}}$ \\
Number of veins per $100 \mu \mathrm{m}$ & 2 & $0.84^{\mathrm{c}}$ \\
Average & & $0.50^{\mathrm{b}}$ \\
\hline
\end{tabular}

Note: ${ }^{\mathrm{a}}$ Low; ${ }^{\mathrm{b}}$ Medium; ${ }^{\mathrm{c}}$ High 

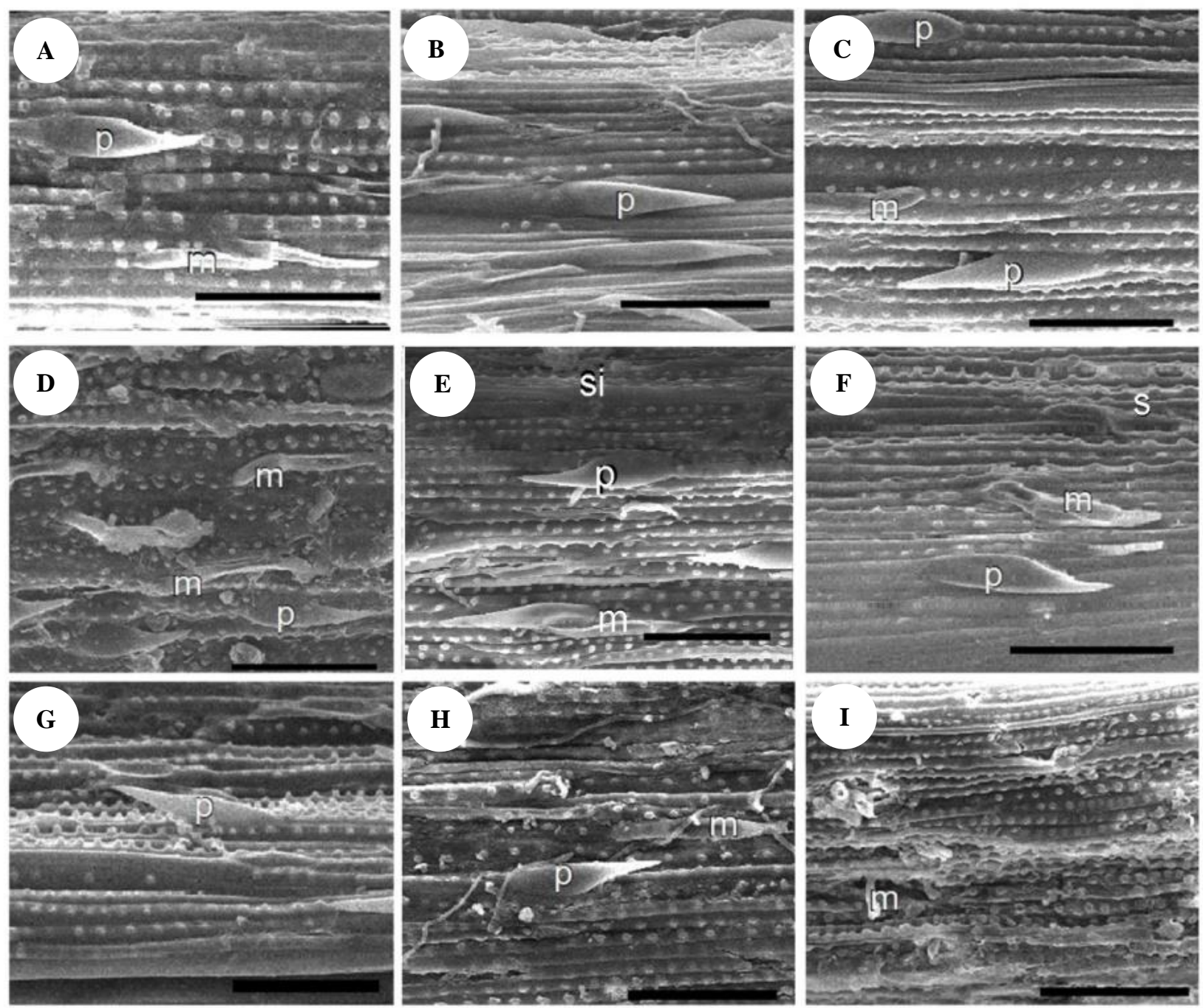

Figure 2. The ultrastructure of the ligule in the tidal swamp rice germplasm of South Kalimantan, Indonesia, was observed by SEM at a magnification of $\times 500$. The name of each cultivar listed in Table 1; p: prickle hair; m: micro hair; s: stomata-like structure; si: silica cell; bar: $50 \mu \mathrm{m}$

Table 5. PCA score of the ligule characters of the tidal swamp rice germplasm

\begin{tabular}{lccccc}
\hline \multicolumn{1}{c}{ Characters } & & \multicolumn{3}{c}{ Components } \\
\cline { 2 - 6 } & PC1 & PC2 & PC3 & PC4 & PC5 \\
\hline Prickle hair density & 0.28 & 0.49 & -0.11 & -0.03 & -0.11 \\
Micro hair density & -0.04 & 0.14 & -0.63 & 0.20 & 0.12 \\
Stomata-like density & -0.08 & 0.51 & 0.07 & -0.09 & -0.42 \\
Silica cell density & 0.25 & -0.35 & -0.03 & -0.28 & 0.24 \\
Prickle hair pattern & 0.31 & 0.28 & 0.03 & -0.06 & -0.01 \\
Micro hair pattern & 0.18 & 0.29 & 0.03 & -0.30 & 0.52 \\
Prickle hair length $(\mu \mathrm{m})$ & 0.33 & -0.14 & 0.19 & 0.30 & -0.40 \\
Prickle hair width $(\mu \mathrm{m})$ & 0.35 & 0.09 & 0.41 & 0.23 & 0.01 \\
Micro hair length $(\mu \mathrm{m})$ & 0.41 & -0.27 & 0.12 & -0.15 & -0.09 \\
Micro hair width $(\mu \mathrm{m})$ & 0.43 & -0.05 & -0.16 & 0.10 & 0.21 \\
Distant between veins $(\mu \mathrm{m})$ & 0.12 & -0.28 & -0.43 & -0.22 & -0.47 \\
Distance between papillae $(\mu \mathrm{m})$ & 0.00 & -0.06 & -0.09 & 0.74 & 0.19 \\
Number of veins $/ 100 \mu \mathrm{m}$ & -0.35 & -0.09 & 0.38 & -0.04 & 0.05 \\
Eigenvalues & 4.43 & 2.30 & 1.68 & 1.57 & 1.42 \\
Percentage & 34.08 & 17.70 & 12.92 & 12.06 & 10.93 \\
Cum. Percentage & 34.08 & 51.79 & 64.71 & 76.77 & 87.70 \\
\hline
\end{tabular}




\section{Discussion}

\section{The ligule ultrastructure}

The ligule is one of the important organs in rice plants. Physiologically, this organ can protect the plant from excluding water, dust, or harmful spores from the outside environment (Zhu et al. 2013). Furthermore, through this organ, one can also distinguish the rice plants from other grasses, and the genus Oryza (Nayar 2014). In this study, we found the unique features of the tidal swamp rice ligule ultrastructure (Figure 2). In general, this organ is composed of large trichomes (prickle hair), small trichomes (micro hair), stomata-like structure, and silica cells, as well as the papillae that line along the veins. According to Chaffey (1983), the rice ligule is composed of these organs and completed with the long cells and the short cells. However, these observations were carried out using a phase-contrast microscope, not SEM (Chaffey 1983).

In the tidal swamp rice observed, all ligule components were shown differently in the characteristics, density, and patterns (Table 2 and 3). The prickle hairs, for example, were seen both in the costal (upper side) and intercostal (between) regions of the long cell rows. This component is medium-sized, unicellular prickles with barbs as long as their bases (Figure 2). According to Chaffey (1983), the barb appears to be developed from the base of the apex, then leads to the top of the ligule.

Unlike the prickle hairs, the micro hairs were seen only in the intercostal region, and all appeared to be bent at right angles near their bases, pointing to the apex. This component comprises two cells of two cells, namely the proximal (basal) and the distal (apical) cell. The proximal cell was more inflated than the distal (which more often appeared absent) but less than half the latter's length. However, the distal cell walls appeared thinner than those of the proximal. Thus, some researchers referred to these as 'poils bicellulaires' or 'poils bj' (Chaffey 1983). As with the prickle hairs, the micro hairs were found throughout the length of the ligule, but reduced in frequency near the apex.

Another case with stomata-like structures, these were seen in the intercostal regions as a single row on either side of the veins. They seemed to be most commonly associated with the two marginal (i.e. the lateral vein nearest the margin of the ligule) veins, but on one occasion were observed alongside a median vein near the apex of the ligule. The structures, which looked like typical rice stomata, as reported by Chaffey (1983), were of a lowtriangular shape with two parallel dumb-bell shaped guard cells, each with an adjacen subsidiary cell bearing a few papillae (Figure 2-F). So far, they have not been observed along any veins, nor have any been seen at vein endings.

\section{Genetic diversity and relationship}

Regarding the diversity, the tidal swamp rice shows a medium level, indicated by Shannon's index of 0.50 (Table 4). According to Schierenbeck (2017), the level of genetic diversity is depends on several factors, such as the temporal scale, dispersal events, bottlenecks followed by population growth, and gene flow among populations. In addition, this level of genetic diversity is often affected by numerous factors such as the breeding system, seed dormancy and dispersal mechanism, geographic variation and range, life span and other life history traits, natural selection, and the history of populations (Huang et al. 2016).

In this case, the breeding system leading to bottleneck and inbreeding is the most probable factor for tidal swamp rice of South Kalimantan, Indonesia. In addition, it may be related to the local culture of farmers that generally use their seeds for replanting in situ (Mursyidin et al. 2017). Compared to our previous study (Mursyidin et al. 2019) using morphological markers, this germplasm shows a relatively higher diversity with a Shannon index of 0.41 .

The results of PCA and UPGMA revealed that this landrace was divided into three groups. In this case, Sardani as an outgroup were clustered into the second group and joined together with other South Kalimantan cultivars. Mursyidin et al. (2018) reported that this landrace clustered into the same three groups and showed differentiation among members using the pollen ultrastructure. For example, in the study, Sardani has joined with only Siam Gadis. Following the morphological markers (Mursyidin et al. 2019), this landrace generated six clusters, where Sardani separated alone from others.

However, this diversity and relationship of the tidal swamp rice are very useful in supporting the development of the new superior cultivars (Joshi et al. 2018). In other words, a clear understanding of genetic diversity and relationships is essential for the effective conservation and utilization of rice genetic resources in the future (Lee et al. 2015).

In conclusion, while the tidal swamp rice of South Kalimantan, Indonesia, shows the unique characteristics of ligule ultrastructure, both in the density and their patterns, further analysis revealed that this germplasm has a medium level of genetic diversity. Thus, this information may be useful in supporting the development of new rice cultivars, specifically for the tidal swamp areas and local rice conservation in the future.

\section{ACKNOWLEDGEMENTS}

We thank the Director of the Indonesian Swampland Agricultural Research Institute (South Kalimantan, Indonesia) for providing Sardani (an outgroup cultivar) for this study.

\section{REFERENCES}

Amanullah, Fahad S, Anwar S, Baloch SK, Saud S, Alharby H, Alghabari F, Ihsan MZ, Ihsan FA. 2017. Rice crop responses to global warming: An overview. In: Amanullah, Fahad S (eds.). Rice-Technologi and Production. IntechOpen. DOI: 10.5772/68035.

Azeez MA, Adubi AO, Durodola FA. 2018. Landraces and crop genetic Improvement. In: Grillo O (eds.). Rediscovery of Landraces as a Resource for the Future. IntechOpen. DOI: 10.5772/intechopen.75944

Chaffey NJ. 1983. Epidermal structure in the ligule of rice (Oryza sativa L.). Ann Bot 52: 13-21. DOI: 10.1093/oxfordjournals.aob.a086546.

Chaffey NJ. 2000. Physiological anatomy and function of the membranous grass ligule. New Phytol 146 (1): 5-21. DOI: 10.1046/j.1469-8137.2000.00618.x.

Collard BCY, Beredo JC, Lenaerts B, et al. 2017. Revisiting rice breeding methods: Evaluating the use of rapid generation advance (RGA) for 
routine rice breeding. Plant Prod Sci 20 (4): 337-352. DOI: 10.1080/1343943X.2017.1391705.

Fukagawa NK, Ziska LH. 2019. Rice: Important for global nutrition. J Nutr Sci Vitaminol (Tokyo). 65: S2-S3. DOI: 10.3177/jnsv.65.S2.

Huang W, Zhao X, Zhao X, Li Y, Lian J. 2016. Effects of environmental factors on genetic diversity of Caragana microphylla in Horqin Sandy Land, northeast China. Ecol Evol 6 (22): 8256-8266. DOI: $10.1002 /$ ece3.2549

Ishii T, Numaguchi K, Miura K, Yoshida K, Thanh PT, Htun TM, Yamasaki M, Komeda N, Matsumoto T, Terauchi R, et al. 2013 OsLG1 regulates a closed panicle trait in domesticated rice. Nat Genet 45 (4): 462-465. DOI: $10.1038 / \mathrm{ng} .2567$.

Islam MZ, Khalequzzaman M, Prince MFRK, Siddique MS, Rashid ESMH, Ahmed MSU, et al. 2018. Diversity and population structure of red rice germplasm in Bangladesh. PLos One 13 (5): e0196096. DOI: 10.1371/journal.pone.0196096.

Joshi BK, Gurung SB, Bhandari B, Gauchan D. 2018. Intra-varietal diversity in landrace and modern variety of rice and buckwheat. Agric Environ 19: 1-8. http://himalayancrops.org/wpcontent/uploads/2018/08/Intra-varietal-diversity-JAE-Joshietal2018.pdf

Kasem S, Waters DLE, Rice NF, Shapter FM, Henry RJ. 2011. The endosperm morphology of rice and its wild relatives as observed by scanning electron microscopy. Rice 4: 12-20. DOI: 10.1007/s12284011-9060-4.

Khan MH, Dar ZA, Dar SA. 2015. Breeding strategies for improving rice yield: A review. Agric Sci 6 (5): 467-478. DOI: 10.4236/as.2015.65046.

Kovach WL. 2007. MVSP 3.1: Multivariate Statistical Package. Kovach Computing Services, Wales, UK.

Lee KJ, Lee J-R, Lee G-A, Lee HS, Kwon SI, Cho Y-G, Cho Y-H, Ma KH, Lee S-Y, Chung J-W. 2015. Genetic diversity among Korean rice landraces (Oryza sativa L.) based on characters and SSR markers. Plant Breed Biotechnol 3 (3): 216-225. DOI: 10.9787/PBB.2015.3.3.216.

Lee J-S, Chebotarov D, Platten JD, McNally K, Kohli A. 2020. Advanced strategic research to promote the use of rice genetic resources. Agronomy 10 (11): 1629. DOI: 10.3390/agronomy10111629.

Mursyidin DH, Nazari YA, Daryono BS. 2017. Tidal swamp rice cultivars of South Kalimantan Province, Indonesia: A case study of diversity and local culture. Biodiversitas 18 (1): 427-432. DOI $10.13057 /$ biodiv/d180155.

Mursyidin DH, Purnomo, Sumardi I, Daryono BS. 2019. Phenotypic diversity of the tidal swamp rice (Oryza sativa L.) germplasm from South Kalimantan, Indonesia. Aust J Crop Sci 13: 386-394. DOI 10.21475/ajcs.19.13.03.p1268.

Mursyidin DH, Sumardi I, Purnomo, Daryono BS. 2018. Pollen diversity of the tidal swamp rice (Oryza sativa L.) cultivars collected from South Kalimantan, Indonesia. Aust J Crop Sci 12 (3): 380-385. DOI 10.21475/ajcs.18.12.03.pne751.

Nayar NM. 2014. Origins and phylogeny of rices. Academic Press, Oxford.
Nourollah A. 2016. Genetic diversity, genetic erosion, and conservation of the two cultivated rice species (Oryza sativa and Oryza glaberrima) and their close wild relatives. In: Ahuja MR, Jain SM, eds. Genetic Diversity and Erosion in Plants. Springer International Publishing Switzerland.

Patra BC, Ray S, Ngangkham U, Mohapatra T. 2016. Rice. In: Genetic and Genomic Resources for Grain Cereals Improvement, Elsevier Inc., New York.

Rabara RC, Ferrer MC, Diaz CL, Newingham MaC V, Romero GO. 2014. Phenotypic diversity of farmers' traditional rice varieties in the Philippines. Agronomy 4 (2): 217-241. DOI: 10.3390/agronomy4020217.

Rabara RC, Ferrer MC, Jara-rabara J, Sotto RC. 2018. Securing diversity for food security: The case of conservation and use of rice genetic resources. in: Celik O (eds.). New Vision of Plant Science. DOI: 10.5772/intechopen.77216.

Rao IS, Neeraja CN, Srikanth B, Subrahmanyam D, Swamy KN, Rajesh K, Vijayalakshmi P, Kiran TV, Sailaja N, Re P, et al. 2018. Identification of rice landraces with promising yield and the associated genomic regions under low nitrogen. Sci Rep 8: 9200. DOI: $10.1038 / \mathrm{s} 41598-018-27484-0$.

Roy SC, Shil P. 2020. Assessment of genetic heritability in rice breeding lines based on morphological traits and caryopsis ultrastructure. Sci Rep 10: 7830. DOI: 10.1038/s41598-020-63976-8.

Samal R, Roy PS, Dash AK, Rao GJN, Bharathkumar S, Subudhi HN, Reddy JN. 2016. Genetic diversity in the rice landraces (Oryza sativa L.) of coastal Sundarbans (India) and their adaptation to the local saline condition investigated both at molecular and physiological level. Acta Physiol Plant 38: 56. DOI: 10.1007/s11738-015-2046-X.

Sánchez E, Espinoza AM. 2005. Ultrastructure of Oryza glumaepatula, a wild rice species endemic of tropical America. Revista de Biologia Tropical 53: (1-2): 15-22.

Sánchez E, Montiel M, Espinoza AM. 2003. Ultrastructural morphologic description of the wild rice species Oryza latifolia (Poaceae) in Costa Rica. Revista de Biologia Tropical 51: 345-354.

Sánchez E, Quesada T, Espinoza AM. 2006. Ultrastructure of the wild rice Oryza grandiglumis (Gramineae) in Costa Rica. Rev Biol Trop 54 (2): 377-385. DOI: 10.15517/rbt.v54i2.13878.

Schierenbeck KA. 2017. Population-level genetic variation and climate change in a biodiversity hotspot. Ann Bot 119 (2): 215-228. DOI: 10.1093/aob/mcw214.

Simpson MG. 2019. Evolution and diversity of vascular plants. In: Plant Systematics (Third edition). Elsevier Inc., New York.

Sinha AK, Mallick GK, Mishra PK. 2015. Grain morphological diversity of traditional rice varieties (Oryza sativa L.), in Lateritic region of West Bengal. Int J Conserv Sci 6 (3): 419-426.

Wambugu PW, Furtado A, Waters DLE, Nyamongo DO, Henry RJ. 2013. Conservation and utilization of African Oryza genetic resources. Rice 6: 29. DOI: 10.1186/1939-8433-6-29.

Zhu Z, Tan L, Fu Y, Liu F, Cai H, Xie D, Wu F, Wu J, Matsumoto T, Sun C. 2013. Genetic control of inflorescence architecture during rice domestication. Nat Commun 4: 2200. DOI: 10.1038/ncomms3200. 